\title{
Afrika Sanatının Koruyucu İşlevi Ekseninde Nick Cave'in Sanat Pratiği
}

\author{
Nick Cave's Art Practice within The Scope of the Protective Function of African \\ Art
}

\author{
Mine Değirmenci Aydın \\ Dr. Öğr. Üyesi, Ordu Üniversitesi, Güzel Sanatlar Fakültesi, Heykel Bölümü \\ email: minedeirmenci@gmail.com (DORCID ID: https://orcid.org/0000-0001-6652-6601
}

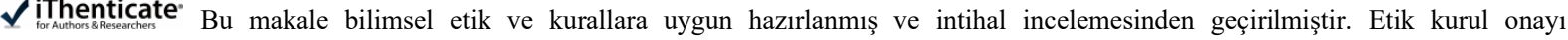
gerektirmemektedir.

Atıf (APA 6)/To cite this article

Değirmenci Aydın, M. (2021). Afrika sanatının koruyucu işlevi ekseninde Nick Cave’in sanat pratiği. Atatürk Üniversitesi Güzel Sanatlar Enstitüsü Dergisi, 27(46), 294-301. https://doi.org/10.35247/ataunigsed.858371
\end{abstract}

Makale Gönderim Tarihi/Received: 11/01/2021

Makale Kabul Tarihi/Accepted: 08/03/2021

Makale Yayın Tarihi/Published: 30/03/2021

Review Article/Derleme Makale

\section{Öz}

$\mathrm{Bu}$ araştırmada, genellikle heykel, dans ve performans sanat1 üzerine üretimler yapan Nick Cave'in "soundsuit" olarak adlandırdığ 1 ses giysilerinin, koruyuculuk işlevi noktasında, Afrika heykeliyle olan analojik ilişkisinin incelemesi amaçlanmıștır.

Nick Cave'in, ilki 1992 olmak üzere 2020 li y1llara gelinen süreçte sanatsal üretimlerinde 500'den fazla soundsuit yaptığı görülmüștür. Giyilebilen bu tam vücut heykeller kişinin cinsiyetini, ırkını, kimliğini gizleyerek koruma işlevi görürler. Soundsuitler, danteller, boncuklar, kumaşlar, tüyler, ağaç dalları ve bitpazarından alınma günlük nesnelerle kaplanmıș yüzeyleriyle, Afrika danslarında kullanılan kostümlerle benzerlik gösterir. Ayrıca Afrika halklarının korunmayla ilgili içüdüsel ilişkisi üzerine yaptığı heykellerin Nick Cave'in üretimleriyle anlamsal yakınlığı olduğunu söylemek mümkün görünmektedir.

Çalışmada Afrika heykeli ve Nick Cave'in sanat pratiği üzerine alan yazını incelendiğinden doküman analizi yöntemi kullanılmıștır. $\mathrm{Bu}$ yöntemle elde edilen verilerin içerik analizi yapılmıştır. Araştırmada sanatçıya ait sanatsal uygulamaların koruyucu bir özellik taşıması Afrika heykeliyle olan ilişkisi noktasında incelenmiștir. Sanat pratiğinde koruyucu ișlev vurgusu sanatçının verdiği röportajlarda ve yazılı kaynaklarda görülmüștür.

Anahtar Kelimeler: Nick Cave, Ses Giysi, Koruyucu Heykel, Afrika Sanatı

\begin{abstract}
This study aims to analyze the analogical relationship of the "soundsuits" by Nick Cave, who usually produces works on sculpture, dance and performance art, with African sculpture at the point of protective function,

Starting in 1992, Nick Cave has made more than 500 soundsuits until today. These wearable full-body sculptures function to protect the person's gender, race, and identity by hiding them. Soundsuits are similar to the costumes used in African dances, with their surfaces covered with lace, beads, fabrics, feathers, branches, and everyday objects taken from the flea market. Moreover, it is possible to say that the sculptures he made on the instinctive relationship of African peoples with protection have a semantic closeness with Cave's productions.

Since the literature on African sculpture and Nick Cave's art practice is analyzed, the document analysis method is used in this study. The content analysis of the data obtained by this method was conducted. In the research, the protective nature of the artistic practices of the artist is examined at the point of its relationship with African sculpture. The emphasis on protective function in art practice has been seen in the interviews and written sources of the artist.
\end{abstract}

Keywords: Nick Cave, Soundsuit, Protective Sculpture, African Art

\section{Giriş}

Sanat eserlerinin koruyuculuk işlevi incelendiğinde, primitif halklardan başlayarak 2020 y1lına kadar gelinen zaman aralığında, sanatta koruyucu işlevin izlerine rastlamak mümkün görünmektedir.

Primitif halklarda büyüsel amaçlarla yapılan heykeller koruma işlevi görmüşler, halkı doğaüstü güçlerden korumuşlardır. İlkel halklar için bir kulübe ve imge arasında yararlılık açısından hiçbir fark yoktur. Kulübeler doğa olaylarından ve kendilerini yaratmış ruhlardan korurken; imgeler de gerçeküstü güçlerden korumuşlardır (Gombrich, 1999, s. 39). Ritüellerde kullanılan heykeller hastalık ve kötülüklere karşı koruyucu görev üstlenmiş büyüsel yapılardır. Ritüellerde maskeler, totem heykelleri, totem direkleri, hayvan figürleri, tılsımlar, çeşitli müzik aletleri ve taşlar şeklinde yer almışlardır.

Primitif halklar, manizm inancıyla atalarının ruhunu anarken büyük heykel uygulamaları yapmış, totemizm inancına bağlı olarak bazı bitki, hayvan ya da eşyaların kendilerini koruduğuna inanmışlardır. Bu anlayış onların sanatsal yaratımlarına kaynaklık etmiştir. Doğanın açıklanamayan güçlerine hâkim olmak istemişler ve totemlere tapan bu insanlar "ölüm okları" adı verilen heykeller yapmışlardır. Her şeye hâkim olduklarına inanılan insan üstü güce sahip, kötüye yönelmiş manevi varlıklar olarak Şeytan fikrinin de görüldüğü doğa halklarında, şeytan motifli maskelerle başka kabilelere korku verecekleri düşüncesi hakimdir (Turani, 1979, s. 39-40). 
Bu çalışmada, Nick Cave'in sanat pratiğinde koruyucu işlevi olan çalışmaları ve Afrika sanatıyla benzer yönleri incelenmiştir. Cave'in üretimlerinde Soundsuit olarak adlandırdığı insanı dış dünyaya karşı koruyan tam vücut giysi şeklinde oluşturulmuş heykelleri ve performanslarına yer verilmiştir. Cave'in üretimlerinde Afrika sanatında görülen ritüellerin ve heykel sanatı örneklerinin hem biçimsel hem de korumayla olan ilişkisi noktasında benzerlikler taşıdığı görülmüştür.

\section{Yöntem}

Bu çalışmada Nick Cave'in Soundsuit olarak adlandırdı̆̆ı yapıtların Afrika Sanatı'nda koruma işlevi taşıyan çalışmalarla ilişkisini incelemek amaçlanmıştır. Konuyla ilgili alanyazını incelendiğinden doküman analizi yöntemi kullanılmıştır. Çalışmanın amacını gerçekleştirmek için ihtiyaç duyulan yazılı ve görsel materyallere ulaşmak amacıyla literatür taraması yapılmış ve ayrıca internet ortamından da faydalanılmıştır. Nick Cave ve Afrika sanatı üzerine yazılmış yazılı kaynaklara ve görsel dokümanlara ulaşılmış, sanatçının dergi ve internet ortamındaki söyleşileri incelenmiş, internet ortamından yapıtların görsellerine ve performans videolarına ulaşılmış, doküman incelemesiyle elde edilen verilerin içerik analizi gerçekleştirilmiştir.

\section{Bulgular}

\subsection{Afrika Sanatında Koruma}

Afrika halklarının korunmayla olan içgüdüsel ilişkisi bir çocuğun duygularıyla benzerlik gösterir. Çocuk onu koruyan anneden ayrılıp yatağa gittiğinde çok korkabilir. Ancak çocuğa yalnız olmadığını hissettirecek bir oyuncak ya da başka bir nesne verildiğinde çocuğun huzur içinde uyuması sağlanabilir. Çocuk içgüdüsel olarak koruyucu işlevi cansız bir nesneye yükler. Afrika insanının yaptı̆̆ı şey bundan farksızdır. (Segy, 1958, s. 5)

Kongo kültüründe, minkisi (tekil nkisi) olarak bilinen içinde ruh barındığına inandıkları heykeller yapılmıştır (Farting, 2017, s. 199). Çeşitli malzemelerle oluşturulan son derece karmaşık bu heykeller, genellikle insan figürü şeklinde yapılmış ve Nkisi Nkondi olarak adlandırılmıştır. Nkondi, avcı anlamına gelmektedir. Nkisilerin nadir olarak da köpek ya da maymun biçiminde oluşturulduğu görülmüştür. Nkisilerin içindeki ruhları harekete geçiren arabulucular Nganga olarak adlandırılmış ve heykeller Nganga'nın gözetiminde bir oymacı tarafından yapılmıştır. Nganga, ruhu aktive etmek için çoğunlukla, yalayarak mühürlediği, yaşayan ve manevi dünyayı bir araya getirdiğine inandıkları çivileri heykelin üzerine çakmış ve böylelikle figürleri harekete geçirmiştir. Çiviler çoğunlukla boyun ve gögüs çevresinde yoğunlaşmış, bu figürleri güçlü kılmış, dolayısıyla ruhu güçlendirmiştir. Böylelikle ruhun yardım yeteneğinin arttığı düşünülmüştür. Bunun yanı sıra çivilerin başka anlamlar içerdiğine yönelik yaklaşımlarda görülmüştür. Ağrısı olan hastanın ağrıyan bölgesine heykel üzerinde çivi çakılmak suretiyle analoji büyüsü yapılarak tedavi etmek, heykelin içindeki ruha hatırlatma yapmak ve suçluları cezalandırmak gibi amaçları da olabilmektedir. Nganga'nın, ruhu harekete geçirmek için çivi ve sert malzemelerin yanında, iplere ve kumaşlara dügümler attı̆gı, figürün karnındaki oyuğa ayna veya büyülü ilaç, tüy, k1l, diş gibi malzemeler yerleştirdiği, kendini ve hastayı boyadığı bilinmektedir (Güvenkaya, 2019, s. 14-20).

\section{Görsel 1}

Power Figure: Male (Nkisi)

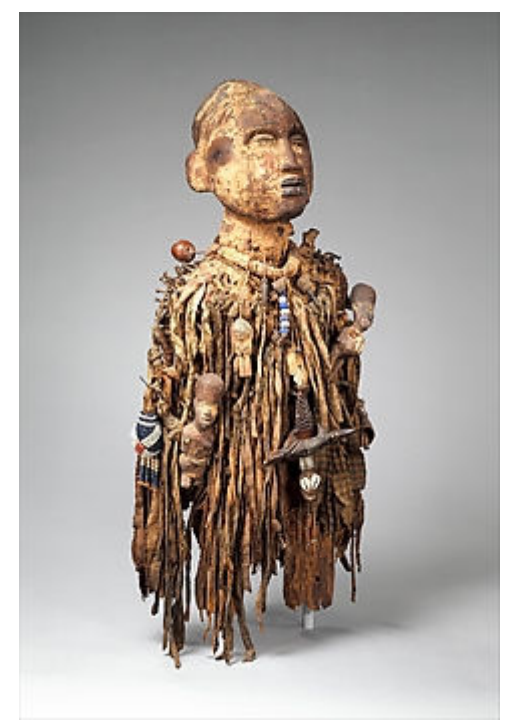

(Nganga, 19-mid-20 yy). 


\section{Görsel 2}

Power Figure (Nkisi N'Kondi: Mangaaka)

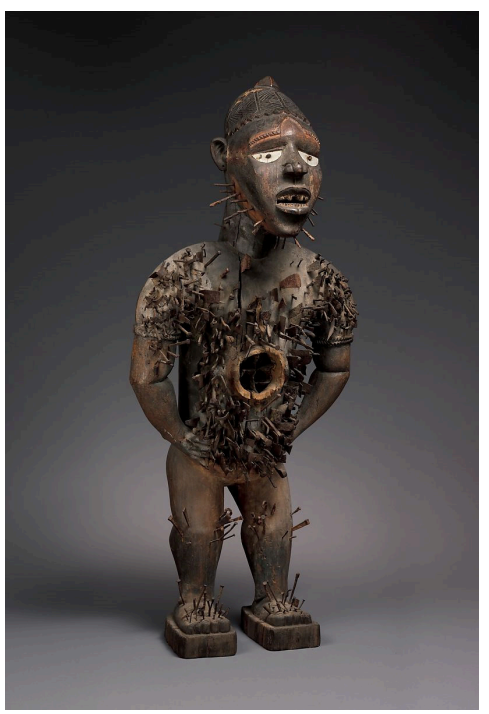

(Kongo sculptors and ritual specialists, 19. yy).

Kongo insanının sanatsal üretimleri, karmaşık kompozisyonlarıyla görüntülerin gerçekçi bir şekilde yorumlanmasına eğilim gösteren çeşitli heykellerde ifade edilir (Shakarov ve Senatorava, 2015, s. 106). Görsel 2 'de görülen çivili heykelde Kongo insanının bir ruhu uyandırmak ve onun korumasını kazanmak için heykeli çivileyerek uyardığı görülür. (Delafosse, 2012, s. 154).

Afrika danslarına bakıldığında, geleneksel dansların bireysel değil, daha çok toplu olarak gerçekleştirildiği görülür. Afrika toplumunda davul çalma, dans performansında insanları bir araya getirir. Davulun sesiyle dans başlar. Bu aidiyet ve dayanışma duygusu için firsattır. Oluşan Kolektif yapıyla her yaştan ve her kesimden insanın bağlantı kurduğu inancını taşırlar. Bazı dini, ruhani ve başlangıç dansları dışında kalan danslara izleyicilerin katılımında bir sakınca bulunmamaktadır. Böylece seyirciler de performansın parçası haline gelir (African dance, t.y.).

Afrika halkları tarafından gerçekleştirilen bu dans ve ritüeller yüzyıllardır süregelmekte ve günümüzde de sanatın birçok alanında sanatçılara ilham kaynağı olmaktadır.

\subsection{Nick Cave'in Koruyucu Heykelleri}

Nick Cave, 1959'da ABD’nin Missouri eyaletindeki Fulton'da dünyaya gelmiştir. Tekstil odaklı görsel sanatlar eğitimi almıştır. Ayrıca koreograf ve aktivist Alvin Ailey’den dans dersleri alan sanatçı, heykel, dans ve performans sanatçısı olarak üretimlerini gerçekleştirmiştir. Soundsuit (Sesgiysi) olarak isimlendirilen melez denilebilecek yaratıcı uygulamalarıyla sanat dünyasında ün kazanmıştır. Çalışmalarının kavramsal çerçevesini rrk, cinsiyet ve kimlik konuları oluşturur.

Nick Cave'in kimlik konusuna dikkat çeken soundsuitleri; önyargıya karşı insanı korumak için çeşitli malzemelerin duyumsal, dokulu ve karmaşık montajlarıyla kılık değiştiren, insanı dış kültürden koruyan zırh görevi görürler. Sanatçının tam vücut elbisesi şeklinde tanımlayabileceğimiz bu yapıtları, hareketle ses çıkaran birtakım nesnelerle donatılmış, adeta bir ritüel ya da karnavalist bir atmosferi gözler önüne serer.

Cave, Rodney King'in 1991'de Los Angeles’taki polis memurları tarafından acımasızca dövülmesine gösterdiği tepkiyle 1992 Los Angeles isyanlarının yarattığı travmatik süreci yansıtmak için ilk Soundsuit' ini gerçekleştirir. Rodney'in siyah bir adam olarak yaşadığı talihsiz olayların ne anlama geldiğini, çoğunluğun beyaz olduğu Cranbrook sanat Akademisi'nde siyah bir öğrenci olarak tecrübe etmiş ve bu durumlar onu sanatsal pratiğinin gidişatına yön vermesi anlamında motive etmiştir. İlk Soundsuit'ini dallardan oluşturan sanatçı, bu malzemeyle siyah insan arasında kurduğu analojik ilişkiyi, parkta otururken yerde önemsiz bir dalı fark etmesi üzerine ilişkilendirir. Onun için yerdeki dallar tıpkı siyah bir insan gibi atılmış ve reddedilmiştir. Kimliğin rolü, değersiz hissetme, reddedilme gibi konular üzerine düşüncelerini yoğunlaştırır. Yerdeki dalların yüzlercesini toplayıp birleştirerek dalın bireysel statüsünü ve gücünü değiştirir. Bu dallar kollektif eylemlerin sosyal adaletsizliklere karşı gücüne gönderme niteliği taşır. Bir araya getirilmiş bu sıradan, atıl dallar, pürüzlü, sert, dinamik, garip ve tanıdık biçimiyle güç kazanır; dans ve müzikle hareketlendiğinde heybetli bir yapıya bürünür (Courtney, 2015). 


\section{Görsel 3}

The First Soundsuit

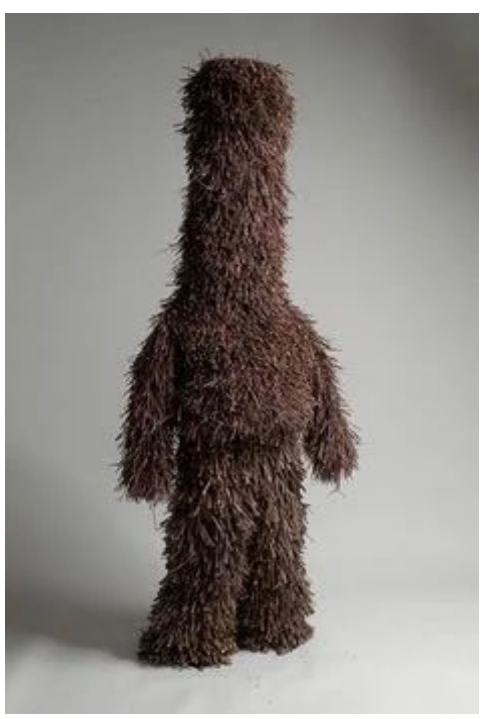

(Cave, 1992).

Cave, Görsel 3'de görülen ilk soundsuit'ini, dalların uçlarına delikler açıp, teller yardımıyla bu dalları birbirine bağlamak suretiyle oluşturmuştur. "Son halini görene kadar bunun bir soundsuit (sesgiysi) olduğunu bilmiyordum. Ama içine girince, hareket ettiğimde birbirine çarpan dallardan hışır hışır ses geldiğini fark ettim" der. Bu, sanatçının daha sonra yapacağı çalışmaların çıkış noktasıdır. Sesi işlerinde keşfeden sanatçı ilerleyen süreçte düğmeleri, boncukları vb. çok çeşitli malzemeleri soundsuit' lerinde denemiş ve giysiyi düş kurduğumuz bir yer haline getirmek istediğini dile getirmiştir (Wilson, 2015, s. 90).

\section{Görsel 4}

TM 13

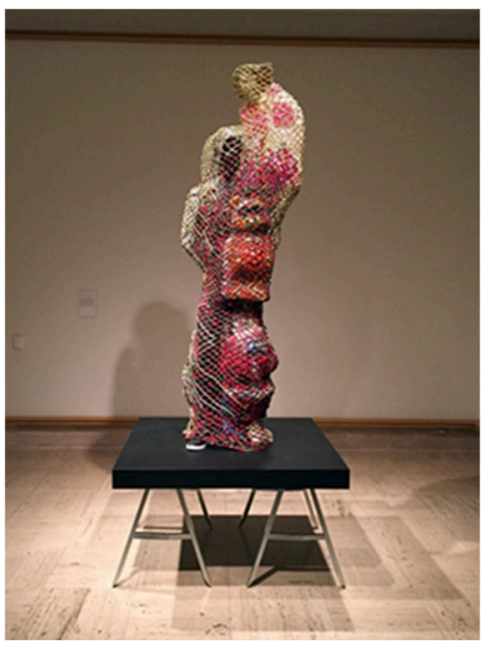

(Cave, 2015a).

Görsel 4'de görülen TM 13 adlı çalışmada, 2015 'te Trayvon Martin adında 17 yaşında içinde market ürünleri olan bir paket taşıyan siyahi bir gencin mahalle bekçisi tarafindan öldürülmesi üzerine yaptığı heykel Cave'in kimlik konusuna dikkat çektiği bir diğer çalışmadır. Heykelin üzerinde kullandığı malzemeler her yerde ulaşılabilen değersiz malzemelerdir. Bunun bilinçli bir tercih olması muhtemeldir. Çalışmada yüzü net yapılmamış siyah bir manken, bireye değil; çokluğa işaret eder. Renkli boncukla örülmüş bir ağın içerisinde bir noel baba, oyuncak ayı ve figürün omuzundaki plastik bir meleğe dramatik bir şekilde yaslandığı görülür. Yüzeyi kaplayan ağın altında nesneler çocukluğun, masumiyetin ifadeleri olarak figürle beraber hapsolmuşlardır. A ̆g yüzeyin altında ayrıca boru temizleme fırçaları, boncuklar ve metal testereler yer alır. Sanatçı, önyargı ve empati gibi konulara dikkat çekmek için çalışmalarının zemin hazırlamasını ve bir sanatçı olarak sivil sorumluluğu olduğunu dile getirir. Bu noktada sanatçı "ngangalar” gibi katalizör görevi görür.

Yaptığı bir röportajında; Karanlık bir noktadan yola çıktığı performans-heykel olarak da adlandırdığı Soundsuit'lerin eğlenceli bir görüntüsü olduğu söylemlerine karşı, çalışmalarını öyle görmediğini söyler. Sanatçı 
izleyenlere eğlenceli gelen şeyin nostaljiden kaynaklandığını düşünür. Cave'e göre; bu, izleyenleri soundsuitlerin içine çekmek için geliştirdiği bir stratejidir. İçerideki derin ve radikal anlamları izleyicinin duyumsayabilmesinin yolunu açan dış görünüşün rahatlatıcı ve erişilebilir olmasıdır. Sanatçı insanların zorluklardan uzak durma eğilimlerinin olduğu kanaatindedir. Son derece renkli yüzeyiyle içeri çekilen izleyici karanlık ve politik bir süreci deneyimlemek zorunda kalır.

Cave, atölye çalışmalarını grup çalışması şeklinde ilerletirken, Soundsuitlerin yüzey bezemelerinde çok sayıda çalışan bulundurur. İşi inşa ederken herkesin aşina olduğu çeşitli malzemelerin değerinin değiştirilmesiyle ilgili konular üzerine düşünürken, aynı zamanda sanat ve zanaat konularının tartışıldığı alanlar yaratmaktan ve bunların üzerine konuşmaların yapılmasından hoşnut olduğunu dile getirir.

Sanatçı, yüzeyin üzerini bezerken malzeme çeşitliliği içinde bir diyalog oluşturur. Farklı parçaları yan yana getirerek denemeler yaparken, nesneleri inceler, ortaklıklar ve ilişkiler kurar. İki parçayı bir araya getirirken bunların yarattığı ruh ve enerjiyle ilgilenir. Bulunan bir nesneyi alır ve istediği yeri bulana kadar vücudun etrafında hareket ettirir ve uygun bir yer bulduğunda yerleştirdiğini söyler. Daha sonra aradaki parçaları bir harç gibi kaynaştırma ve bir arada tutmak amacıyla kompoze eder. Her zaman bunun üzerine düşündüğünü ve yeni yollar aradığını ifade eder (Sollins, 2018).

Heykel ve diğer sanat dalları arasındaki sınırların belirsizleştiği postmodern süreçte heykel izleyicinin kendisini izlemesinden çok deneyimlemesini veya düşünmesini ister. (Huntürk, 2011, s. 16) Bu bağlamda Nick Cave'in çok çeşitli malzemelerle bezenmiş hareketli kostüm heykelleri postmodern anlayışta izleyicinin içine girip deneyimleyebileceği gerçeklikten uzaklaştığı bir hayal alanı sunar. Tekstil eğitiminin yanı sıra dans dersleri de alan sanatçı her zaman harekete ilgi duymuş çok yönlü bir vizyona sahip olması onun üretkenliğini tetiklemiştir. Heykel sanatı açısından bakıldığında hareket ve ifade gibi iki önemli unsurun yanı sıra heykelin estetik ifadesinde kullanılan malzeme büyük önem taşır. (Şişman, 2006, s. 24)

$\mathrm{Bu}$ tam vücut giyilebilir heykeller, kullanıcının ırkının, cinsiyetinin, yaşının, cinsel kimliğinin ve sınıfının tüm işaretlerini gizleyerek dayanıklılık ve koruma biçimi olarak işlev görürler. Afrika'nın tören kostümleriyle bazı benzerlikler taşıyan Cave' in Soundsuitleri, boyalı insan saçı, plastik düğmeler, boncuklar ve tüyler de dahil olmak üzere, büyük ölçüde bit pazarlarından elde edilen günlük malzemelerden üretilir. Cave'in rengarenk görünümlü Soundsuits' leri performansta kullanılan çıngıraklarla kimi zaman bir bandoyu andırır durumdadır (Karafin, 2018). Performanslarında farklı toplulukların paylaşabileceği bir deneyim alanı sunar.

\section{Görsel 5}

Up Right Atlanta Performansı

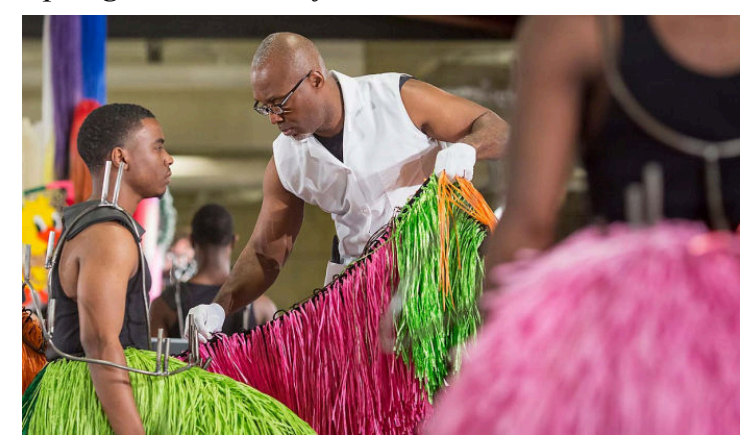

(Cave, 2015b).

\section{Görsel 6}

\section{Soundsuits Heard}

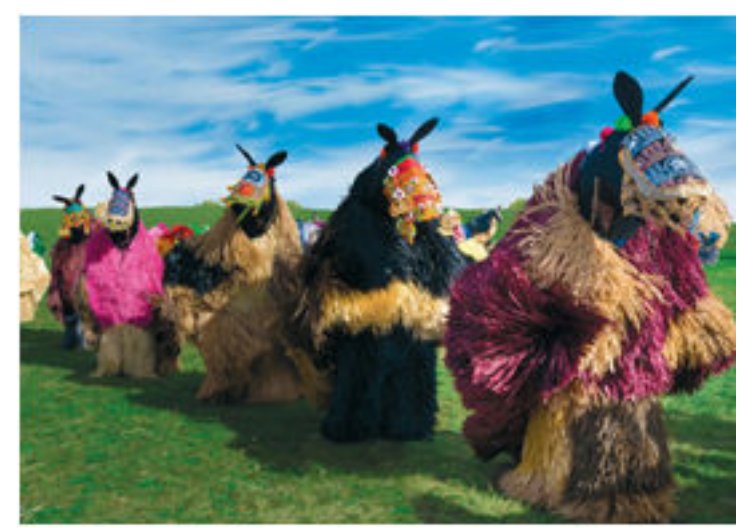

(Cave, 2012). 
Çoğunlukla performanslarda insanı kamufle eden bu heykelsi kostümler diyebileceğimiz oluşumlar, heykelin ana dili olarak kabul edilen biçim dilinden 1şık-gölge, dolu-boş, sert-yumuşak, yatay-dikey, katı-organik, içbükey-dış bükey, işlenmiş-kaba bırakılmış, monoton-hareketli, büyük-küçük, yuvarlak düz gibi karşıtlıkları gözler önüne serer. (Huntürk, 2011, s. 15)

Cave, ırksal profil, kimliğin rolü, değer kaybetme, kategorize etme gibi düşünceler etrafında oluşturduğu soundsuitlerini tıpk1 Afrika törenlerinde kullanılan heykelsi nesneler gibi nesnenin faydası etrafında merkezlendirir. Cave'in heykellerinde vücudu kamufle eden, ırk, cinsiyet ve sınıf gibi mefhumlar gizlenirken; İnsan derisini göstermeyen bu oluşumlar ikinci bir katman gibi karşımıza çıkmaktadır. Sanatçı, izleyiciyi bu yapıtlar karşısında yargılamadan bakmaya zorlar. (Kinsella, 2016)

Rengarenk malzemelerle bezeli göz alıcı bu kostüm heykellerin yarattığı görsel gerginlik aracılığıyla fiziksel bir manipülasyondan söz ederken estetik prestij tanımlarını sorgular. Neyin değerli ve prestij oluşturduğuyla ilgili sorular sorar. Bitpazarı ve tasarruf mağazalarından alınan malzemelerle oluşturulan soundsuitlerde bu kaynaklar özellikle tercih edilmiş, atılacak kadar değersiz kabul edilen nesneler yeniden kullanılmıştır. Sanatsal yaratım sürecindeki bu tercihler kavramsal çerçeve açısından konuya yaklaşıldığında bilinçli seçim noktasında insanların değerli olanı yeniden sorgulamasını sağlar. Çeşitli malzemelerle oluşturduğu bu karmaşık sanat objeleriyle estetik prestiji ortadan kaldırmış, böylece çalışmaları deneyimleyen izleyici de bu fikirle kuşatılmıştır (Williams, 2015)

Sanatçı çalışmalarında sesi bir alarm şekli olarak kullandığını söyler. Her zaman duyulmak zorunda olmadığını, bir ritim oluşturmak için desenin yüzeye nasıl kurulduğunun duyulabileceği, rengin bir ses duygusu yaratabileceği düşüncesindedir. Örneğin bir polis arabasının sireninin duyulmadan kırmızı 1şıklarının o sesi yaratabileceğini ifade eder. Sözlü iletişim olmadan hareket yoluyla nasıl iletişim kurulabileceği üzerine düşünür. Örneğin yere bastırılan ayak nasıl güçlü bir iletişim kurar? gibi soruları tartışır (Lee, 2018)

Parlak, renkli ve yoğun dekoratif objelerden oluşan tüm soundsuitler moda, kostüm, heykel, dans, performans vb. çağdaş sanat kesişmesinde yoğun doku ve mücevher hissi uyandıran yüzeyleri ve ses çıkaran yapılarıyla performanslarda da tüm görkemiyle yerlerini almışlardır. Soundsuitler bilinen insan bedeni formunun geleneksel algısını değiştirmiş, genişleyen, yükselen değişen ölçüleriyle dekoratif, özenle süslenmiş yüzeyleriyle, insana ait referanslar sunmuş; fakat ırksal farkı ortadan kaldırmıştır. İnsan bedenine atıflar yapan bu yapılar için izleyicilerden içlerindeki gerçek insan bedenlerini hayal etmeleri beklenmiştir. (Lamm, 2017, s. 36)

Cave'in heykelleri her türlü kategoriye karşı bir kimliksizleşme önerisi kurması anlamında queer kuramla ilişki kurar. David J. Getsy’nin bahsettiği; "kimliğin istikrarının stratejik biçimde kesilmesi” ve "gölgede bırakan gücün dağıtılması" fikrinden hareketle Oueer kuram çerçevesinde Cave'in çalışmalarının bu fikri destekler nitelikte olduğunu söyleyebiliriz (Lamm, 2017, s. 38).

\section{Görsel 7}

Farklı Dönemlere Ait Soundsuit Örnekleri
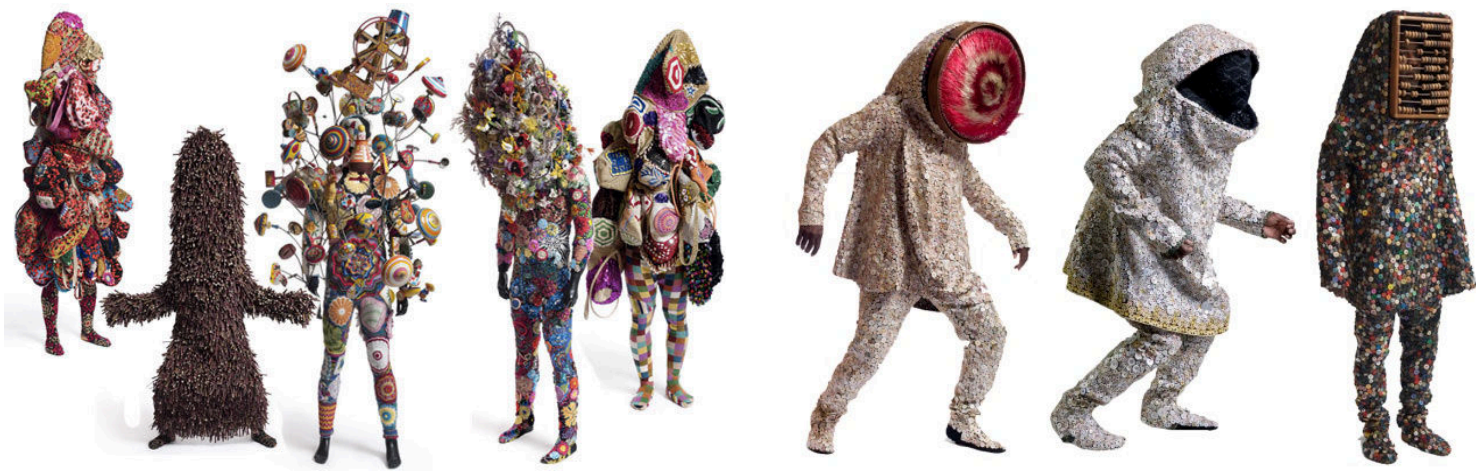

(Cave, t.y.).

Görsel 7' de görüldüğü üzere izleyicinin içindeki figür hakkında bir fikir oluşturmakta zorlandığg, kalın yüzeyiyle koruma duvarı gibi işlev gören bu yapıyı çekici hale getiren şey, Cave'in boncuklar, çiçekler ve danteller gibi son derece feminize nesnelerle ve malzemelerle çalışmasıdır. Bu görüntünün izleyicide dişil ve duyarlı bir çağrışım yarattığını söylemek mümkün görünmektedir. 


\section{Görsel 8}

New York Grand Central Terminali'nde Gerçekleştirilen Performans

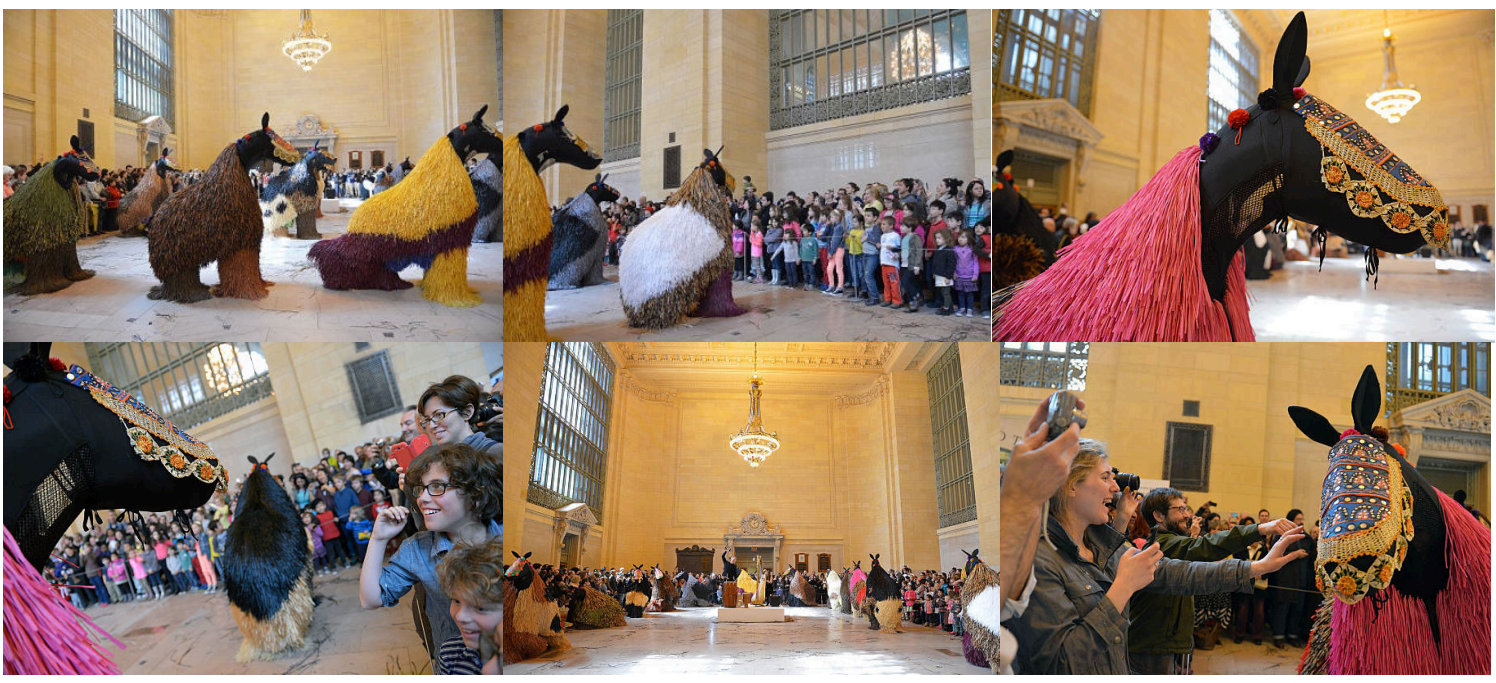

(Cave, 2013).

Cave'in Görsel 8'de görülen, 2013 'te New York Grand Central Terminali'nde gerçekleştirdiği performansta 30 Soundsuit kostümlü, canlı at boyutlarına yakın, iki kişiden oluşan figürleri, bir at gibi koşup dans ederler. Cave, Soundsuit'in içindeki iki kişinin kolektif çalışmasının oluşturduğu düşünceyle dünyada kolektif bilincin oluşması ve nasıl hareket etmemizle ilgili sorular üzerine düşünmemizi ister. Çalışmasının içinde bulunduğumuz çok kültürlü dünyayla ilgili olduğunu dile getirir (Obkircher, 2020).

Sanatçı, performanslarında Afrika etnik gruplarının ritüellerinden ilham alır. Çok fazla davulun çalındığı ve coşkulu dansların olduğu bu ritüeller izlendiğinde Cave'in performanslarındaki müzik, kostümler ve dans arasındaki benzerliği görmek mümkündür.

\section{Sonuç}

Bu çalışmada Nick cave'in ırk,cinsiyet, kimlik vb. konulara dikkat çekmek için oluşturduğu koruma olarak işlev gören "Soundsuit" olarak adlandırdığı, insan bedenini tam olarak kapatan heykelsi oluşumları incelenmiştir.

Araştırmada sanatçının 1992'den başlayarak 2020'li yıllara kadar uzanan süreçte uyguladığı 500'den fazla soundsuit uygulaması olduğu görülmüştür. İlk soundsuitini 1992'de ağaç dallarından oluşturan sanatçı, atılacak kadar değersiz kabul edilen dal parçalarıyla siyah insan arasında bir ilişki kurmuştur. Kendisi de siyahi olan sanatçının, deneyimlediği ötekileştirme olgusu çalışmalarında yer almıştır. Soundsuitlerin tıpkı Afrika heykellerinde olduğu gibi nesnenin faydası etrafında merkezlendiğini söylemek mümkündür.

Kongo kültüründe Nkisi Nkondi olarak adlandırılan, içerisinde ruh barındırdığına inanılan heykeller bulunmaktadır. Üzerinde çeşitli malzemeler bulunan son derece karmaşık bir görünüme sahip bu heykeller aracılığıyla Nganga'nın Nkisilerin içindeki ruhları harekete geçirerek arabuluculuk ve iyileştirme görevini üstlendiği görülür. Bitpazarından alınmış çeşitli nesneler ve tekstil malzemeleriyle bezenmiş Soundsuit'lerin karmaş1k görüntüsü Nkisi Nkondi'lere benzemekte ve koruma işlevi üstlenmektedir. Kendini önce haberci sonra sanatçı olarak tanımlayan Cave'in tıpkı Ngangalar gibi aracı olarak hizmet verdiğini söylemek mümkün görünmektedir. Buradan hareketle Cave'in soundsuit'lerine bakıldığında, Nkisi Nkondi'lerle hem biçimsel hem de içerik olarak yakınlık olduğu görülür.

Sanatçının performansları incelendiğinde soundsuitlerin Afrika ritüellerindeki kostümlerle benzerlik taşıdığı görülmüştür. Burada da benzerlik hem biçimsel hem de içerikseldir. Afrika geleneksel ritüellerinde dans bireyselden ziyade toplu katılımla gerçekleşir. Sanatçı bu kolektif yapıdan çok etkilenmiş, kendi performanslarında bu birleştiren bir araya getiren yapıyı kullanmış ve verdiği röportajlarında da sıklıkla ifade etmiştir. Sanatın topluluklar yaratmak ve insanlara yeni platformlar sağlamakla ilgili olduğu düşüncesini savunmuştur.

Afrika ritüellerinde yer alan vurmalı çalgıların performanslarda aidiyet ve dayanışma duygusuna vurgu yaptığı ve insanları biraraya getirdiği görülmektedir. Nick Cave' in performanslarında da vurmalı çalgıların aynı amaçla yer aldığını söylemek mümkündür.

Araştırmada, Nick Cave'in Soundsuit'lerinin Afrika sanatıyla benzer özellikleri ortaya konarak, koruma kavramı özelinde incelenmiştir. Sanatçının Soundsuitlerinin başka kavramlar çerçevesinde incelenebileceği gibi, farklı sanatsal üretimleri noktasında da araştırmaya açık olduğu görülmüştür. 


\section{Kaynakça}

African dance. (t.y.). Wikipedia içinde. https://en.wikipedia.org/wiki/African_dance

Cave, N. (1992). Nick cave first Soundsuit [Heykel]. https://publicdelivery.org/nick-cave-soundsuits/

Cave, N. (2012). Soundsuits Heard [Fotoğraf]. https://publicdelivery.org/\%20nick-cave-soundsuits/

Cave, N. (2013). New York Grand Central Terminali'nde gerçekleştirilen performans [Fotoğraf]. https://www. gettyimages.com/photos/nick-cave-grand-central?phrase=nick $\% 20$ cave $\% 20$ grand $\% 20$ central\&sort=mostpop $\underline{\text { ular }}$

Cave, N. (2015a). TM 13 [Heykel]. http://infinitemiledetroit.com/On_Encountering_Indifferent_Objects.html

Cave, N. (2015b). Up Right Atlanta performansi [Fotoğraf]. https://fluxprojects.org/productions/up-right-atlantanick-cave/

Cave, N. (t.y.). Farkl dönemlere ait Soundsuit örnekleri [Fotoğraf]. http://sumerkatearts.blogspot.com/2012/10/ soundsuits-by-nick-cave.html

Courtney, C. (2015, November-December). Nick Cave on practice, performance and violence [Monografi]. Adobe Airstream Art Music and Film from West. http://adobeairstream.com/art/nick-cave-on-practiceperformance-and-violence/

Delafosse, M. (2012). African art. Parkstone Press.

Farting, S. (2017). Sanatın tüm öyküsü (G. Aldoğan \& F. C. Çulcu, Çev.). Hayalperest Yayınları.

Gombrich, E. H. (1999). Sanatın öyküsü (Ö. Erduran \& E. Erduran, Çev.). Remzi Kitabevi.

Güvenkaya, B. C. (2019). Koruyucu heykeller: Yerli halklarda heykel ve heykelin koruyuculuk işlevi (Tez No. 552321) [Yüksek lisans tezi, Mimar Sinan Güzel Sanatlar Üniversitesi]. Yüksek Öğretim Kurulu Tez Merkezi.

Huntürk, Ö. (2011). Heykel ve sanat kuramları. Şan Matbaası.

Karafin, A. (2018). An ecstatic embrace: Inside the Soundsuits of Nick Cave. Amykarafin. http://amykarafin. com/pdfs/cave.pdf

Kinsella, E. (2016, 2 May). How Nick Cave's Soundsuits made him an art world rock star. Artnet News. https://news.artnet.com/market/nick-caves-soundsuits-made-art-world-rock-star-485522

Kongo sculptors and ritual specialists. (19. yy). Power figure (Nkisi N'kondi: Mangaaka) [Heykel]. The Met Fifth Avenue, New York, NY 10028, United States. https:/www.metmuseum.org/art/collection/search/ $\underline{320053}$

Lamm, K. (2017). The will to Adorn: Nick Cave's Soundsuits and queer reframing of black masculunity. Critical Arts South-North Cultural and Media Studies, 31(3), 35-52. https://doi.org/10.1080/02560046. 2017.1383494

Lee, Y. (2018, 16 Ocak). Nick Cave makes armour for the World's violence. Canadianart. https://canadianart.ca/interviews/nick-cave-makes-armour-worlds-violence/

Nganga. (19-mid-20 yy). Power figure: Male (Nkisi) [Heykel]. The Met Fifth Avenue, New York, NY 10028, United States. https://www.metmuseum.org/search-results\#!/search?q=power\%20figure\%20nkisi

Obkircher, F. (2020, 08 Aral1k). US artist Nick Cave explains how to turn despair into hope. RedBull. https://www.redbull.com/gb-en/theredbulletin/nick-cave-soundsuits-hope-art-interview

Segy, L. (1958). African sculpture. Dover Publications.

Shakarov, A., \& Senatorava, L. (2015). Traditional African art. Mc Farland Company Inc.

Sollins, S. (2018, 28 Eylül). Interview: Childhood Nick Cave. Art21. https://art21.org/read/nick-cave-childhood/ Şişman, A. (2006). Sanata ve sanat kavramlarına giriş. Yaz Yayınları.

Turani, A. (1979). Dünya sanat tarihi (2nd ed.). Türkiye İş Bankası Kültür Yayınları.

Williams, B. (2015). Medium and meaning in Nick Cave's Soundsuit. The first-year papers (2010-present) (s. 14) içinde. Trinity College Digital Repository. http://digitalrepository.trincoll.edu/fypapers/60

Wilson, M. (2015). Çă̆daş sanat nasıl okunur? E. Koyunoğlu (Ed.), F. C. Erdoğan (Çev.). Hayalperest Yayınevi. 